

кандидат філологічних наук, доцент кафедри української мови Житомирського державного університету імені Івана Франка

ORCID: 0000-0003-1599-9964

ktytar@ukr.net

\title{
ФОНЕТИЧНІ ТА МОРФОЛОГІЧНІ РИСИ ПОЛЬСЬКОЇ МОВИ В ПРИВІЛЕЯХ КИЇВСЬКОМУ МІСЬКОМУ МАГІСТРАТОВІ
}

У статті проаналізовано фонетичні та словозмінні ознаки польської мови, виявлені в привілеях Київського міського магістрату. Досліджуваний копіарій створений у першій половині XVIII cm. Збірник документів уміщує грамоти на підтвердження магдебурзького права м. Києву від 1542 до 1649 р., із них упродовж 1542-1608 рр. видано дев'ять привілеїв руською мовою, п'ять латинською та три польською, починаючи з 1615 p. 30 привілеїв

написані польською мовою. Під грамотами записано, щу перекладачами пам'ятки з латинської та польської мов були сотники Антон Трочина та Михайло Якгельницький. У досліджуваному тексті виявлено різні польські рефлекси: неповноголосі форми, $є$ на початку слова, слова без епентетичного л, звукосполуки дл, дз тощо. Позначився також польський вплив на словозміні: уживається значна кількість запозичень із словотвірною моделлю под ... ий із семантикою 'заступник когось... '; виявлені іменники на -ця; називний відмінок множини рясно представлений формами на -ове та ін.

Ключові слова: пам'ятка, рефлекс, неповноголосся, словотвірна модель, словозміна, староукраӥнська мова.

\section{Tytarenko Walentyna. Cechy fonetyczne i morfologiczne języka polskiego w przywilejach} magistratowi miasta Kijów

W artykule przeanalizowano cechy fonetyczne i fleksyjne języka polskiego $w$ przywilejach magistratu miasta Kijów. Zbadany zbiór kopii został ułożony w XVIII wieku. Dokumenty zawieraja gramoty na potwierdzenie prawa magdeburskiego m. Kijowa od 1542 do 1649, w tym w ciagu 1542 - 1608 zostało wydano dziewięć przywilejów w języku ruskim, pięć - w języku łacińskim oraz trzy -

w języku polskim; zaczynając do 1615 roku 30 przywilejów byto napisano po polsku. Pod gramotami byty umieszczone podpisy tłumaczy pamiatki z łacińskiego i polskiego języków setników Antona Trocyny oraz Mychajta Jakhelnickiego.

W zbadanym tekście widać różnego typu polskie refleksy: formy niepetnogłosu, $\boldsymbol{\epsilon}$ na poczatku wyrazu, wyrazy bez epentetycznego л, połaczenie głosek дл, дз i in. Jest także polski wpływ na fleksję: sq używane duża ilość zapożyczeń z modelem słowotwórczym nod ... uй ze znaczeniem 'zastępca kogoś... '; sa rzeczowniki na -ця, Mianownik liczby mnogiej przedstawiony formami na oвe $i$ in.

Wyrazy kluczowe: pamiątka, refleks, niepetnogłos, model słowotwórczy, fleksja, język staroukraiński.

\section{Tytarenko Valentina. Phonetic and morphological features of the Polish language in privileges to the Kyiv City Magistrate}

The article analyzes the phonetic and syllabic features of the Polish language identified in the privileges of the Kyiv City Magistrate. The studied copy was created in the first half of the XVIII century. for own needs by Kozma Krichevets. The collection of documents contains certificates for the confirmation of the Magdeburg Law of Kyiv from 1542 to 1649, of which nine privileges were issued in the Russian language, five Latin and three Polish during the period 1542-1608, beginning 
in 1615. 30 privileges were written. in Polish. The certificates state that the translators of the monument in Latin and Polish were centurions Anton Trotzyn and Mikhail Yakhelnytsky.

Various Polish reflexes are revealed in the text under study: incomplete vowels forms (krolevstvo (kingdom) instead of korolevstvo, krol' (king) instead of korol, zabronyty instead of zaboronyty); words with the sound [je] at the beginning (jedynostajno instead of odnostajno, jedyn instead of odyn, jednogo instead of odnogo), words without epentetic l, sound connections [dl], [dz] for

(neosedlie, dzekan), Polish nasal reflexion (séndomy (p) skog), etc. are rarely detected.

Word change is also affected by the Polish influence: a considerable number of borrowings with the word-forming model pod...yj with the semantics of 'someone's substitute' are used: podskarbyj. Noun forms on... -tsia were found: prodavtsia, derzhavtsia. The nominative plural is abundantly represented by the forms in the -ove: arkhymandrytove, rotmystrove etc.

Thus, in addition to lexical polonisms, the monument features distinctive features of the Polish language at the phonetic and morphological levels, some of which are due to the translational nature of the document, and some were the acquisition of the clerical language of that time.Although much of the text analyzed has been translated from the Polish language, the quantitatively phonetic and morphological features are presented no more than in the original business style texts created in the Ukrainian lands.

Key words: memorial, reflex, incomplete vowels, word-forming model, word-translation, Old Ukrainian language.

Постановка проблеми. Пам'ятки XVIII ст. у мовному плані недостатньо досліджені, частина з них зберігається в архівах, а тому малодоступна для наукового загалу. Окрім того, класичним $є$ погляд мовознавців про те, що староукраїнська мова до кінця XVIII ст. занепала, оскільки вичерпала свої ресурси. Ці твердження спростовують скрупульозні дослідження окремих пам'яток зазначеного періоду, наприклад, різнорівневий опис мови «Наук парафіяльних» І. Гетки [17]. Тому публікація пам'яток та опис їхньої мови часто не лише слугує для накопичення фактологічного матеріалу, а й дає підстави для заперечення певних тверджень або формулювання нових. Мова досліджуваного документа - привілеїв Київського міського магістрату - поки не має системного опису. Мовознавча цінність пам'ятки полягає в тому, що в ній уміщені привілеї оригінальні й перекладні (з латинської та польської мов).

Копіарій, що зберігається в центральному державному історичному архіві України під шифром ф. 62, оп. 1, спр. 1., створений для власних потреб Козьми Кричевця, про що дізнаємося $з$ послівного запису, який проходить на лицьових аркушах книги (2-50): «Сія книга коптя в Глухов переведенни(x) на ма(ло)російскій диалекть привилеиевъ полскихъ королеиї и привилиованними киевскому маистрату древними разними годами наданни(x) $o(m)$ якихъ королей якимъ диалектомь где <,> когда<,> за чиимъ подписомъ и на что с обстоятелни(мъ) при кониу означеніемъ сочинена старателствомъ и коштомь собственнимъ его йлти пана Козми Якимовича Кричевия, бурми(ст)ра киевского, для своеи прива $(m)$ ной и домовой потребности и всяки $(x)$ случаевъ року ... (написано невиразно)», збоку іншим почерком дописано «значить 1665 года». Дата стоїть помилкова, оскільки й К. Кричевець, і сотники перекладацькою діяльністю могли займатися в першій половині XVIII ст.

У збірці зібрані документи на підтвердження магдебурзького права м. Києву з 1542 по 1649 рр. Видавалися ці грамоти руською староукраїнською), латинською та польською мовами. Протягом 1542-1608 рр. видано дев'ять привілеїв руською мовою, п'ять латинською та три польською. Починаючи 31615 р. 30 привілеїв написані лише польською мовою. Із самої пам'ятки дізнаємося, що перекладачами привілеїв з польської та латинської мов були Антон Троцина й Михайло Якгельницький. Відомі роки їх сотницької діяльності, відповідно 1710-1729 та 1717-1728. Мова, якою видані привілеї з королівської резиденції, відображає тогочасну мовну ситуацію на українських землях і мовну політику Речі Посполитої: попри 
те, що руську мову визнавали мовою ділових документів у Люблінській угоді 1569 р., на Варшавському сеймику 1590 р. і до 1669 року в діловодстві ніяких постанов про заборону української мови не видавали, лише на Варшавському сеймі документально затвердили, що король «усю документацію видаватиме польською і латинською мовами» [12, с. 26], а в 1696 p. було прийнято постанову, у якій польська мова визнавалася мовою українських канцелярій $[15$, с. $150 ; 12$, с. $12,16,28]$. Із цього приводу Кеннеді Грімстед зазначила: «Упродовж 30-40-х років XVII ст. мовна ситуація стосовно привілеїв для українських земель, так само як і роль писарів, зазнали ще радикальніших змін, ніж ситуація довкола судових декретів. За винятком кількох підтверджень, старіших угод та копій із давніх документів, занесених до книг руською мовою, актів руською мовою практично вже немає. Понад те, уже в 1631 р. офіційні копії 20 з 22 привілеїв, записаних до двох руських книг того року, виконані по-польському. За 1633-1635 pр. руською мовою записано лише один документ; те саме спостерігаємо в книзі за 1636-1641 pр. Аналогічно в 1645 р. усі сімнадцять привілеїв зареєстровані польською мовою. Характерно, що за 1632, 1641-1644, 1646-1652 pp. у Руській серії не збереглося жодного документа привілейного чи підтверджувального змісту. Це наводить на думку про те, що вони послідовно перестали реєструватися окремо» [6, с. 73].

Аналіз останніх досліджень і публікацій. У статті Г. Наєнко грунтовно описано напрями вивчення писемних джерел та названо представників цих напрямів із вказівкою на праці [14, c. 334-335].

Мову пам'яток XVI-XVIII ст. ділового стилю студіювали багато дослідників як в окремих публікаціях, монографіях, так і в передмовах до видаваних текстів (О. Макарова [10], А. Матвієнко [5], В. Мойсієнко [2; 3; 13], В. Німчук [7; 9], І. Царалунга [1], Л. Ящук [11] та багато інших науковців). Просту мову кінця XVIII ст. на основі пам'ятки «Наукі парафіяльні» [17]. Вплив польської мови в староукраїнських текстах аналізований у працях багатьох науковців, найповніший список наведено в монографії С. Гриценко [5].

Мета статті - проаналізувати вплив польської мови на фонетичному та морфологічному рівнях мовної системи в копіарії привілеїв першої половини XVIII ст., частина з яких перекладена з польської мови на староукраїнську, а тому окремі лінгвальні особливості тексту зумовлені польськомовним та латинськомовним оригіналом.

Виклад основного змісту. Досліджувана пам'ятка виразно насичена полонізмами різних лексико-семантичні групи: очєvи(c)mo 2, суплкдючи 2, уйтуючи 2, продокъ 2 зв., щзодроблико(с)ти 2 зв., привлащаєть 4, иллости 6, zопо(л)на 6, ска(р)бовъ 8 зв., щчєгу(л)ной 131 зв., понева(ж) 132, мочии 132, скутечно(с)ти 132, обтници 132, преложвнства 128 зв., по(с)льиенство 128 зв. та багато ін.

Незважаючи на те, що лексика польського походження в багатьох випадках була невід’ємним елементом, наявні слова 3 польської мови, які вже мали відповідники в українській мові та часто вживалися й у самому тексті привілеїів, зокрема вступна частина


zособно 2 - vсть о(б)щє и ко(ж)доту zосо(б)на 2 зв.; ма(р)цุа 65 зв., мцүға ма(р)та 84 зв. тощо.

Зважаючи на канцелярський стиль, переносилися цілі конструкції: zлимь припадкомъ 6, в цале заховавши 105 зв. (в цุале заховали 116, и в цуале zахо(vu)вати 120), в цале и не нарушоне 63, до оста(m)него кресу живота свовго 112 зв., на сєйме валномъ 131, подаль v моцъ 31 зв., даємо моцъ и вла $(\mathrm{cm}) 45$ зв. Окремого дослідження потребує встановлення, які з них були притаманні загалом для тогочасної канцелярської староукраїнської мови, а які зумовлені польськомовним прототипом.

Нижче детальніше зупинимося на характеристиці наявних у копіарії фонетичних i морфологічних рис польської мови. У досліджуваних привілеях уживаються слова 3 виразними ознаками, властивими польській мові. Наприклад, виявлено неповноголосні 
форми: кролевства 13, кроль 56 зв., zабронғати 22 зв., zабронғаючи 22 зв., кролєвского 95 зв., які залишені в тексті, напевно, під впливом оригіналу, оскільки слова 3 питомою рефлексацією переважають як у таких само словах: королввскимъ 2 зв., оборонитися 3, заборонғають 77 зв., забороннатсе 128 зв., королевствъ 78 зв., королна 65, так і в інших: оборочати 4, короннихъ 4, сторожи 46 зв., оборонб 5, перешкоду 50 зв., перемешкиваючіе


31, о (m) молодиовъ 57, по триста золотихъ 83, оголосити 108, молодихъ 112 тощо. Зауважимо, що на польські неповноголосні форми часто натрапляємо в різножанрових пам'ятках XVI-XVII ст. Частими вони стають до кінця XVII ст., що було наслідком тогочасної мовної ситуації, за якої польська мова була поширилася в писемно-літературній царині й у діловодстві насамперед.

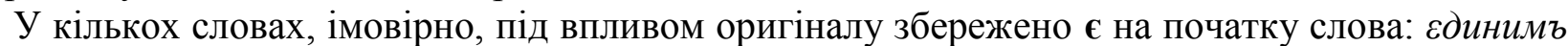
121, єдна 127, عдиностайно 124 зв., окремі написання вживаються паралельно з о: единъ 100 зв. - одно 70 зв., едного 110 зв. - одного 98, еднакъ (в ичллости заховуючи такъ /ғакь/ єднакъ аби се скро(м)не заховоуали) 117 зв. - однакь (при то(мъ) ла(с)кави(м) повволенъю иши(мъ)


на початку слова може бути потрактована і як діалектна (північноукраїнська), проте в пам'ятці відсутні інші виразні поліські риси, наявні в староукраїнських пам'ятках.

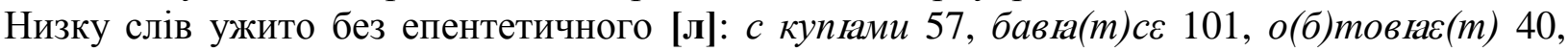

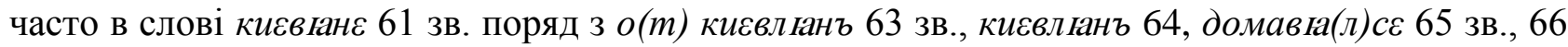

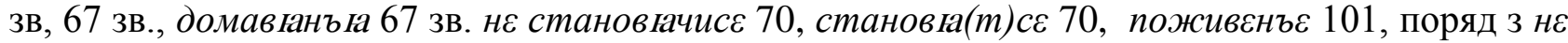
прибавлғаючи 2 зв., поживленъға 101 (пор. в одній грамоті: билъ по(з)ванимъ слушнє о(т) києvғанъ 61 і декре(m) ... покладаний о(m) києвлнанъ быль 63 зв.).

Відображено польську рефлексацію на місці *tj, *gt у лексичних полонізмах обєиъбмо 132, моцъ 31 зв., 45 зв., 95, o(m) плачяєнъға 116.

На місці *е̌ відображено один раз рефлекс ['a] в слові мғановито 111 зв., пор. часте написанням меновите 67 зв., 70, 79 зв., 96 зв., 101 зв., 125 зв.

Польські носові звуки переважно передаються староукраїнськими відповідниками, тобто у та на ['a]: рубанъє 68 зв., взгладъ 68 зв., найпрудшєй 52 і под., хоч засвідчено й ен у слові сендоти (р)ского 39 зв.

Кілька полонізмів зберігають західнослов'янську звукосполуку дл: осе(д)ліе ғако $u$ нвосвдліе 128, осе(д)ліе 128 зв., припадлимъ 104.

Звукосполука дз як фонетична ознака польської мови виявляється в словах рідко: подвовводzєго 63 зв. поряд з по(д)вовводимъ 86 зв., кгродzинского 10, дzєканъ 106 зв., 107,

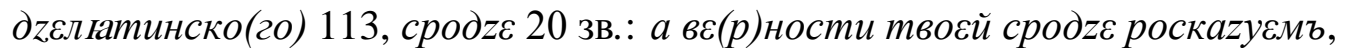

Відчутний вплив польської мови також на морфологічному рівні.

Запозичені з польської мови слова на позначення посад зі значенням 'заступник...', які утворені за моделлю под- ... -ий: подкотороту 11, подка(н)челгари(й) 41 зв., подска(р)бій 18 зв., подчашєго 17 зв., подстаростамъ 115 зв., подвовводzєго 63 зв., з по(д)вовводимъ 86 зв. Як зазначає М. Басай у «Словнику богемізмів», такий словотвірний тип запозичився / поширився в польській мові під чеським впливом і був активним аж до кінця XVIII ст. [16, с. 237].

Ужито кілька іменників чоловічого роду на -ця (-ца), які відмінюються як іменники жіночого роду з основою на -а (-я): продавц̧а 63 зв., райц̧а 125 зв., дєржавц̧а 10, 18. На думку дослідників, вони потрапили в староукраїнську мову під польським впливом [8, с. 10]

Частими в пам'ятці в називному відмінку множини є форми на -ове, які активізувалися під впливом польської мови: вовводове 35 зв., 79 зв., 97, архимандритовє и игуменовє 97, жидовє 32, ассессоровє 80, татаровє 86, антєиєссоровє 112 зв. Пор. поряд різні флексії в наз. відм.

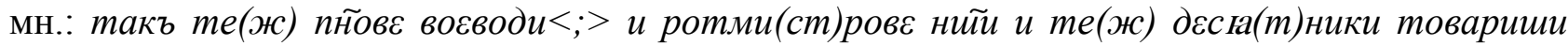

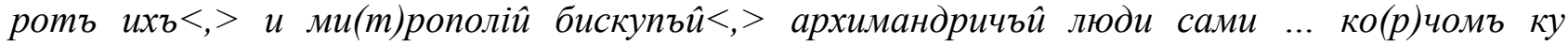


пожи(m)ку свовту бстановлғати ... жадного шинку на продажу де(p)жати не маю(m) 12; i



Під польським впливом залишені в тексті усічені форми прикметників та дієприкметників: ижь прєzвнтованій биль пред нати ли(ст)-приvиле(й) на папери



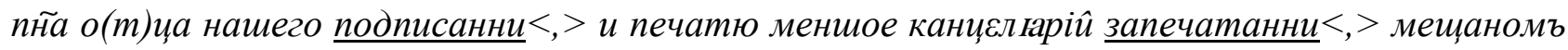

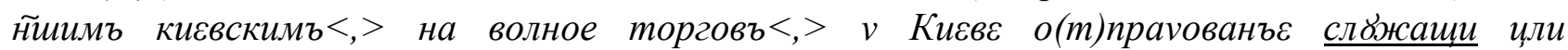
нєнардиони 109, о(т)дленни 110 тощо.

У тексті на позначення чотирьох десятків часто трапляється польська числівникова форма: панованъға королевствъ ниихх по(л)ского четиредестатого 87 зв., панованға ниего


четвє(р)того 113 (двічі), року Гйднға тиснача ше $(\mathrm{cm}) \mathrm{co}(\mathrm{m})$ четиредесна $(\mathrm{m})$ пнатого 121, року Гйднға тисғача шє $(\mathrm{cm}) \mathrm{co}(\mathrm{m})$ четире деска $(\mathrm{m})$ девғато (2о) 121. Подекуди така форма має ще й польське звукове оформлення: а панованға ниого чтиридєскато(го) втораго 23, чтире 98, виявляємо шість разів числівник сорок: року тисғача шестъсоть сорокъ деvғатого 125, сорокъ дввнатій 65, Панованъға ниего по(л)ского сорокъ первого 89 зв.

Частим $\epsilon$ використання залишкових форм допоміжного дієслова в минулому часі: дабисмо 3, надалисмо 17 зв., абихмо 57, аби єсми 68 зв., абисте 57, бистє 57 зв., росказали всмо 69, абисми 52, давалисмо 52, умислили 52 зв., сут 57, деклғаровалисми 86 зв., вираздиилисмо 126 3в. та інші, які теж могли бути поширені під польським впливом [17, с. 237].

Висновки та перспективи подальших досліджень. Отже, на фонетичному та морфологічному рівнях пам'ятка написана тогочасною українською мовою. Описані фонетичні (неповноголосні форми, є на початку слова, звукосполуки дл, дз, слова без епентетичного л тощо) і морфологічні (словотвірна модель под- ... -ий; іменники на -ця) виразні польськомовні риси зумовлені передовсім запозиченою лексикою, оскільки виявлені переважно в полонізмах. Окремі з них потрапляли в текст під впливом польськомовного оригіналу (називний відмінок множини -ове, усічені форми прикметників та дієприкметників, уживання форми чотирдесять / чтирдесять, використання залишкових форм допоміжного дієслова в минулому часі та ін.). Жодна вищеописана риса в подальшому не стала властивою українській фонетиці та словозміні. Перспективними $є$ дослідження графіко-орфографічних особливостей пам'ятки, вияву варінтних слів і форм.

\section{Список використаних джерел та літератури}

1. Акти Вижвівської міської книги XVII ст. / підгот. до вид. І. Б. Царалунга. Житомир : Полісся, 2015. $170 \mathrm{c}$.

2. Акти Житомирського гродського уряду: 1590 рік, 1635 рік / підгот. до вид. В. М. Мойсієнко. Житомир, 2004. 256 с.

3. Актова книга Житомирського гродського уряду 1611 року / підгот. до вид. А. М. Матвієнко, В. М. Мойсієнко. Житомир, 2002. 392 с.

4. Волинські грамоти XVI ст. / упорядн. В. Задорожний, А. Матвієнко. Київ, 1995. 245 с.

5. Гриценко С. Динаміка лексики української мови XVI-XVII ст. Київ, 2017. 934 с.

6. Грімстед К. Руська серія Коронної метрики. Руська (Волинська) метрика. Київ, 2002. С. 29-139.

7. Ділова мова Волині і Наддніпрянщини XVII ст. Зб. док. / підгот. до вид. В.В.Німчук, В. М. Русанівський та ін. Київ, 1981. 316 с.

8. Керницький І. Система словозміни в українській мові. Київ, 1967. 288 с.

9. Книга Київського підкоморського суду (1584-1644). Зб. док. / підгот. до вид. Г. В. Боряк, Т. Ю. Гирич та ін. Київ, 1991. 344 с.

10. Книга Овруцького замкового уряду 1678 р. Вип. 2. / підгот. до вид. О. Ю. Макарова. Житомир, 2013. $244 \mathrm{c}$.

11. Кременецька земська книга 1578 року / підгот. до вид. Л. В. Ящук. Кременець : Кремен.-Почаїв. держ. іст.-архітектур. заповідник, 2018. 300 с. 
12. Кубайчук В. Хронологія мовних подій в Україні (Зовнішня історія української мови). Київ : «K.I.C.», 2004. $168 \mathrm{c.}$

13. Луцька замкова книга 1560-1561рр. / підгот. до вид. В. М. Мойсієнко, В. В. Поліщук. Луцьк, 2013. $733 \mathrm{c}$.

14. Наєнко Г. Фонетико-фонологічна й графіко-правописна системи української мови II половини XVII століття (на матеріалі «Викладу о церкви Теодосія Софоновича»). Rozprawy komisiji językowej. T. LXVI. 2018. S. 333-350.

15. Огієнко I. (Митрополит Іларіон). Історія української літературної мови / упоряд., авт. іст.-біогр. нарису та приміт. М. Тимошика. Київ : «Наша культура і наука», 2001. 440 с.

16. Basaj M., Siatkowski J. Bohemizmy w języku polskim. Słownik. Warszawa, 2006. $502 \mathrm{~s}$.

17. Getka J. Język «Nauk Parafialnych» (1794) - ukraiński wariant prostej mowy końca XVIII wieku. Warszawa : Wydawnictwa Uniwersytetu Warszawskiego, Seria Druga Europa, 2012. 316 s.

\section{References (translated \& transliterated)}

1. Akty Vyzhvivskoi miskoi knyhy XVII st. [Acts of the Vizhiv City Book of the 17th Century]. (2015). I. B. Tsaralunha (pidhot. do vyd.). Zhytomyr: Polissia [in Ukrainian].

2. Akty Zhytomyrskoho hrodskoho uriadu: 1590 rik, 1635 rik [Acts of the Zhytomyr City Government: 1590, 1635]. (2004). V. M. Moisiienko (pidhot. do vyd.). Zhytomyr [in Ukrainian].

3. Aktova knyha Zhytomyrskoho hrodskoho uriadu 1611 roku [Act book of Zhytomyr city government in 1611]. (2002). A. M. Matviienko, V. M. Moisiienko (pidhot. do vyd.). Zhytomyr [in Ukrainian].

4. Volynski hramoty XVI st. [Volyn diploma of the XVI century]. (1995). V. Zadorozhny, A. Matviienko (uporiadn.). Kyiv [in Ukrainian].

5. Hrytsenko, S. (2017). Dynamika leksyky ukrainskoi movy XVI-XVII st. [Dynamics of the vocabulary of the Ukrainian language of the XVI-XVII centuries]. Kyiv [in Ukrainian].

6. Hrimsted, K. (2002). Ruska seriia Koronnoi metryky [The Russian series of Crown Metrics]. Ruska (Volynska) metryka - Russian (Volyn) metric. Kyiv, 29-139 [in Ukrainian].

7. Dilova mova Volyni i Naddniprianshchyny XVII st. [Business language of Volyn and Dnieper region of the XVII century]. (1981). V. V. Nimchuk, V. M. Rusanivskyi ta in. (pidhot. do vyd.). Kyiv [in Ukrainian].

8. Kernytskyi, I. (1967). Systema slovozminy v ukrainskii movi [The system of word change in the Ukrainian language]. Kyiv [in Ukrainian].

9. Knyha Kyivskoho pidkomorskoho sudu (1584-1644) [Book of the Kyiv Submarine Court (1584-1644)]. (1991). H. V. Boriak, T. Yu. Hyrych ta in. (pidhot. do vyd.). Kyiv [in Ukrainian].

10. Knyha Ovrutskoho zamkovoho uriadu 1678 r. [Book of Ovruch Castle Government in 1678]. (2013). O. Yu. Makarova (pidhot. do vyd.). Zhytomyr [in Ukrainian].

11. Kremenetska zemska knyha 1578 roku [The Kremenets Zemsky Book of 1578]. (2018). L. V. Yashchuk (pidhot. do vyd.). Kremenets: Kremen.-Pochaiv. derzh. ist.-arkhitektur. zapovidnyk [in Ukrainian].

12. Kubaichuk, V. (2004). Khronolohiia movnykh podii v Ukraini (Zovnishnia istoriia ukrainskoi movy) [Chronology of Language Events in Ukraine (Foreign History of the Ukrainian Language)]. Kyiv: «K.I.S.» [in Ukrainian].

13. Lutska zamkova knyha 1560-1561 rr. [Lutsk Castle Book of 1560-1561]. (2013). V. M. Moisiienko, V. V. Polishchuk (pidhot. do vyd.). Lutsk [in Ukrainian].

14. Naienko, H. (2018). Fonetyko-fonolohichna y hrafiko-pravopysna systemy ukrainskoi movy II polovyny XVII stolittia (na materiali "Vykladu o tserkvy Teodosiia Sofonovycha») [Phonetic-phonological and graphic-spelling systems of the Ukrainian language of the second half of the seventeenth century (on the material of «An exposition on the Church of Theodosius Sofonovich»)]. Rozprawy komisiji językowej. Dissertations of Language Committee, Vol. LXVI, 333-350 [in Ukrainian].

15. Ohiienko, I. (Mytropolyt Ilarion). (2001) Istoriia ukrainskoi literaturnoi movy [History of Ukrainian Literary Language]. M. Tymoshyk (uporiad., avt. ist.-biohr. narysu ta prymit.). Kyiv: «Nasha kultura i nauka» [in Ukrainian].

16. Basaj, M. \& Siatkowski, J. (2006). Bohemizmy w języku polskim. Słownik [Bohemisms in Polish. Słownik]. Warszawa [in Polish].

17. Getka, J. (2012). Język «Nauk Parafialnych» (1794) - ukraiński wariant prostej mowy końca XVIII wieku [Język «Doctrine of the Parafialnych» (1794) - Ukrainian variant of prostate mowy skin XVIII wieku]. Warszawa: Wydawnictwa Uniwersytetu Warszawskiego, Seria Druga Europa [in Polish]. 